\title{
Theoretical Basis and Practical Strategy for the Reform of the Governance Structure of Local Colleges and Universities
}

\author{
Xiaoming Li, Naizhu Huang, Jiaming Zhong and Shouping Gao* \\ XiangNan University, Chenzhou, 423000 \\ xnxyhnzh@163.com \\ *The corresponding author
}

\begin{abstract}
Keywords: Local colleges; The governance structure; Reform; The theory and practice
\end{abstract}
\begin{abstract}
Local colleges and universities in the process of transition to applied technology University, management system is unsound and the governance of low ability is quite prominent. Local universities transition development need to break through the mode of highly centralized administrative system, developing a multi-governance model of cooperation, interaction and balance between local government, local university, market mechanism and civil society, constructing a multiple governance structure made up of limited government, open market, normative society and autonomous University. Local university governance structure reform needs to push forward steadily according to "policy leading strategy, problem oriented strategy, innovation leading strategy".

Local colleges are general institutes of higher education which funds are directly allocated by the provinces, autonomous regions and municipality directly under the central government, its education aim is to cultivate high-quality applied skilled personnel for the regional economic and social development. The Ministry of education, the national development and Reform Commission, the Ministry of Finance on the guidance Guiding opinions to guide some local colleges and universities transition to applied colleges emphasize that local colleges and universities should explore and establish "a cooperative education and cooperative governance mechanism which participated by schools, local, industry, enterprises and the community", actively accelerate the transformation and development of local colleges and universities. As an important part of national governance, Under the background of the transformation of management to governance, Promoting the modernization of management system and management ability in local colleges is not only an urgent and realistic task an it is also an important issue to promote comprehensive education reform.
\end{abstract}

\section{Firstly, Raise of Problem}

The meaning of the word "governance" is refers to rule, control, guidance and control in both ancient Chinese and ancient Greek language. Since the 1990's, western scholars have given new meaning to "governance" and the meaning is far from the original meaning. In 1995,The UN global governance commission put forward the idea in our global partners research report:" governance is the sum of many ways that public or private individuals and institutions to manage their common affairs, it is a continuous process to coordinate the conflicting or different interests and take joint action, there are four basic characteristics: governance is not a set of rules, also is not an activity, but a process, the basis of the governance is not a control process, but coordination; governance is involved in the public department, also including the private department; governance is not a formal system, but the continuous interaction".

Thus, as a new management concept, management means to readjust the relationship between the country and civil society relationship, government, social organization, market, and individual citizens as the stakeholders are the main governance subject of public services, under the common goal of mutual trust and depend on each other, sharing resources, cooperation, interaction and mutual participate in public policy and provide public services; it means that management is not only characterized by the development of a certain system arrangement, but also show the development process, constantly seeking out a good governance path that can solve management 
predicament and "taking people as the center", solving social problems, the innovation of public service, improve citizens' welfare; It means that the function of the government and its leader behaviors will also change, from the traditional direct orders, rules and regulations, monitoring management way to establish a Shared vision, build strategic vision and development ability, using wisdom or counsel, aggregation and integration of a variety of resources and power, promote cooperation among stakeholders, sharing, coordination and conflict resolution and management quality. Duderstadt pointed out:" university is facing a great challenge, it is not fiscal constraints, also is not the efficiency of students' ability and research institutions, and it is not in the current mechanism transformation. The biggest challenge lies in university's internal and external social and university management measures and management methods of reform". At present, the local colleges and universities transform to an applied technology universities, the imperfect management system, low management ability is quite prominent, the transformation of local colleges development needs to break through the highly centralized administrative system, construct a multiple governance mode which is cooperate, interact and balanced between local government, local universities, the market mechanism and civil society ,constructing a multiple governance structure between limited government, open markets, standardize society and independent college.

\section{Second, the Basic Theory of Local University Governance Structure Reform}

Local university governance structure reform from ruling to governance "Copernicus type" change its ultimate goal is the pursuit of good governance. The so-called good governance is good governance or effective governance, it is a kind of art between government and other governance department, it is a social management process that can let the public interest maximization. The essence of good governance is the cooperation management that government and citizen govern the public life, it is a new relationship between novel political state and civil society, it is in a good state. Local university governance structure reform to achieve good governance theory is based on market-oriented, participative governance theory, governance theory solution type governance theory.

Market-oriented Governance Theory. Governance theory is that the state and society, blurring the responsibility of the boundary between public and private, public affairs management needs the government, social organizations and individuals to work together with the full participation. Market-oriented governance theory point of view is that the private sector management methods almost is inherently superior to the traditional public sector management method of" improving the efficiency of the government organization is the best or even the only way to use some kind of based on market mechanism instead of traditional bureaucracy". Its theoretical basis is: first, it believe that the market mechanism is the allocation of social resources are the most efficient mechanism, if the government intervention is close to the market model, then the more likely to get the best results. Second, the government officials as "economic man" role is often ignored in the process of the pursuit of self-interest maximization of public affairs, in charge of the market mechanism compared with no one is responsible for the bureaucracy, it has better accountability mechanisms. Third, the market mechanism that the administration cancel government privilege, and open labor market competition to attract more outside object. Market-oriented governance theory demands change the traditional concept of "government is irreplaceable entity", change the monopoly on public services, allow and encourage private organizations to participate in and provide more effective public services. Government as yuan governance role in the face of failure, of course, take "as a different policy proposals of the main organizers dialogue, it has the responsibility to ensure that each subsystem to achieve a certain degree of unity overall organization, as makers of rules and regulations, make the parties to follow and apply the rules and regulations to achieve their purpose, that is to say, in the other subsystem failed as the supreme organ of authority is responsible for the last remedy measures". In the field of higher education, market-oriented governance theory calls for the government to change the situation of higher education administrative monopoly, advocate introducing market mechanism into development of colleges and universities, in the university governance cost - benefit way to consider the investment in higher 
education, speed up the implementation from the concept of "bureaucratic" to the concept of "responsibility", make the bureaucracy to get a sense of mission and sense of control and at the level of awareness, to improve the management efficiency of the government department in charge of education in colleges and universities, promote the development of higher education.

Participative Governance Theory. Participation means involved, public participation in social management is an important symbol of civilization progress. Participatory governance is primarily the disadvantages caused by the diagnosis level restraint, advocate the flat organization structure, in the public decision-making method to ensure the public interest to consultations and negotiations. Participative governance theory is: the basic hypothesis of social policy making process, level control as the main characteristics of bureaucracy in the experts don't have access to all required information, making policy excluding the public to participate in important decision-making, can lead to policy mistakes. Because "both public sector and private sector, not an individual actors can have all the knowledge necessary to solve the problem of comprehensive, dynamic, complexity and information; there are no actors have enough knowledge and ability to apply all effective tool" . Modern university organization has become increasingly complex and function diversity, if not a lot to absorb talented, there is sense of responsibility of social university of citizen participation in decision-making, only single main body to make a decision by the government department in charge of education, it is difficult to guarantee scientific and rationality of university decision-making. Based on stakeholder theory, the government in higher education decision making, as long as the other stakeholders can reflect desire, reflect all the stakeholders, it can change the government's management mode of university unilateral control, forming a broad participation of stakeholders co-governance mode.

Solution to the System of Governance Theory. Solution system regulation means lifted, and regulation means management and control, it is refers to the government adopt the way of develop and implement the laws and regulations forced action management object, the change of government expected to promote society. Solution system of governance theory purpose is to remove too much government regulation, gives all kinds of social organizations, including the university more autonomy and freedom to management, improve the social creativity and initiative of the organization. Around the world, too much government deregulation, has become the basic trend of government reform. Ostrom in the description of the modern government legislation as legal system lead to flood situation, said: "the rules and regulations can be seen everywhere, any reason to maintain the rule of law have been abandoned, when pave the way for his bribery into price, law becomes a temporary Qian Qi, eventually everybody will bribe everyone" [], even in the legalization process of the developing countries, the spread of legislation also can be seen everywhere, the government, social organizations, enterprises and institutions have been make a lot of can't fulfill the rules and regulations. In fact, the regulation is like a double-edged sword, is not the more the better, the key is to scientific and reasonable, as some scholars point out that: "the regulation is not appropriate, good man also do bad things; right of rules and regulations, the bad guys can also do good thing" .

\section{Third, the Practice of Local University Governance Structure Reform Strategy}

In urgent need of transformation of local university to the university of applied technology development through the reform of the governance structure, perfect the university governance system, build application technology education culture atmosphere, building" pay attention to skills and abilities" respect the campus cultural environment, cultivate college students' professionalism and quality of skilled talents.

Policy Leading Strategy. In 2013 the third Plenary Session of the 18th CPC Central Committee to make the deployment of comprehensive reform in the field of education strategy, clearly put forward the improvement and development of China socialist educational system, promote the educational modernization of governance systems and governance capacity as the overall goal, to promote the management and running score from the basic requirements for the transformation of government functions as a breakthrough, the formation of the government's macroeconomic 
management, school autonomy, new pattern.2014 community wide participation in the year the State Council promulgated the "decision on accelerating the development of modern occupation education >:" occupation colleges to develop occupation education embodies the characteristics of constitution and law, improve the governance structure, improve governance capacity. The establishment of schools, industry, enterprise, community to participate in the school council or the board of education.2015 the Ministry, the national development and Reform Commission, Ministry of Finance jointly issued on the Ministry of < guide local colleges and universities to change the application type The proposed guidance on exploration and establishment of "school, local, industry, enterprises and the community to participate in cooperative education, cooperative governance mechanism". This series of national level policy provides a new opportunity for reform and the dividend policy for local colleges and universities to promote the modernization of governance systems and governance capacity, the local universities should take the opportunity to emancipate the mind, pioneering enterprising, accelerate school governance structure and governance system reform process, focus on innovation driven development, manufacturing China 2025, Internet, innovation and public entrepreneurship peoples, "a major strategic The Belt and Road" and other countries, the establishment of the integration of production and education, cooperative education personnel training mode, implement professional chain and industrial chain, the course content and the occupation standard, the teaching process and the production process of docking, cultivate a sense of social responsibility, applied talents of innovation spirit and practice ability, enhance the service area by local universities Social development capacity, service industry enterprise technology progress ability.

Problem Oriented Strategy. The problem oriented strategy is the local colleges and universities should be good at study and found the prominent problems in the university governance and to solve the problem as the core of the development of the reform program, the implementation plan and process route. Discover and solve problems is the fundamental motive force of the development of human society and progress, adhere to the problem oriented, daring to try, dare to break through comprehensive reform of school management system and to achieve a breakthrough.

(1)Local Colleges and universities Council reform practice. The local council construction is to enhance the contact and cooperation between University and society, improve the internal governance structure in Colleges and universities and to promote the construction of modern university system China features important content of.2014 regulations of the General Higher School Council issued by the Ministry of education (Trial) pointed out: "higher education colleges and universities means the State Council held according to the social law independent school, set up by the participation of representatives of the relevant aspects, support the development of school counseling, consultation, consideration and supervision mechanism, is to achieve scientific decision-making, democratic supervision in Colleges and universities, an important form of organization and institutional platform for social participation. At present, many local colleges and universities or not set up the Council, or nominal, main problems performance: one is unclear: most of the Council as advisory body in the position in the internal governance structure of the lack of clear Clear definition of responsibility is unknown; two: the University Council is primarily responsible for financing and providing services to schools, did not play in Promoting College Independent Schools for the community, improve the internal governance structure; three is the composition and operating rules are not standardized: the University Council universal school by relevant enterprises or on behalf of the donor, did not reflect the broad on behalf of the independent schools for the community school requirements. Therefore, local colleges and universities in the reform of the governance structure should be in accordance with the "Regulations of the General Higher School Council (Trial) > spirit stepped up to build Council, Council staff organized by the relevant government departments, units, institutions, on behalf of clients and other interested parties, as the realization of the decision the higher school of democracy, democratic supervision, important governance body and organizational forms of social participation, perform the following duties: one is the participation in decision-making consultation: The Council may school development goals, strategic planning, discipline construction, professional setting, the annual budget report, the major 
reform initiatives, major issues to prepare or revise the articles of association, to carry out consultation or participate in the consideration of discussion; two is to promote social cooperation: colleges and universities to carry out social cooperation, cooperation, collaborative innovation overall program and important agreements etc. that can be referred to the Council advice, the Council can also study school funding for the community, the goal of integration of resources, planning, supervision and financing; the three is to carry out monitoring and evaluation: the board of directors to absorb all relevant aspects of representatives, may be an important mechanism for school self-supervision and the introduction of social supervision, to participate in the school review the quality of the school's characteristics and assess the quality of education, and put forward reasonable suggestions or opinions.

(2)Practice of "de- administration" in local colleges and Universities. For a long time, due to the impact of the traditional bureaucratic system, local university administrative power and academic power asymmetry, administrative power and academic power overstepping phenomenon is very serious more than the academic committee of $70 \%$ of the newly established local colleges and universities there are school leaders, functional departments and faculty leadership, full-time teachers on behalf of the very few. Professor Qiu Bo pointed out: public schools in the "their bureaucracy is very rigid, hierarchical highly differentiated rules cumbersome, too formal, so that the healthy development of the school needs professional autonomy and outstanding performance. They lost the bureaucracy mode is not suitable for the Management of colleges and universities is the low efficiency of management: first, improve the quality of education service not only requires teachers to have superb teaching skills, but also need to give them a professional autonomy, can be said to a university's competitive advantage lies in the teachers and students Many aspects of the pursuit of freedom to be encouraged. And the bureaucracy management mode cannot meet these requirements second, control of bureaucratic; management from top to bottom needs a series of quantitative standards, and many aspects of educational activities and their results are difficult to quantify, resulting in education management is difficult to understand the effect and process of their specific the fai Lure of their work for the whole process to control and management third, the school's primary; goal is to meet the needs of customers, rather than accept the orders, but the bureaucratic management emphasis is rigid procedures, lower level to the higher level, lack of response ability to various demands from the service object.

The reform of the governance structure of local colleges and universities to implement the "administrative" management practice is of great significance. The so-called" administrative": one is the government going to school two school internal administrative decentralization, decentralization to the teachers and students. In recent years, our country University "to the administrative" voice continued: 2010 Premier Wen Jiabao said online communication with friends" the tendency of administrative education needs to change, it is best not to set up the university administrative level," said the same year secretary Yuan Guiren said: "education reform, exploring the establishment of the school management system features and supporting policies, the phasing out of the actual existence of the administrative and executive level management mode", promulgated in 2010, "national long-term education the reform and development plan" clearly pointed out:" with the national institutions classification reform, exploring the establishment of the school management system features and supporting policies to overcome The tendency of administration, the abolition of the actual existence of the administrative and executive level management mode ". Now, some colleges and universities to the chief of the fire has been lit:" 8 with senior cadres from Yimeng old revolutionary base areas of Linyi University of a new round of full competition for professional and technical positions to the "official" as a professor; Beijing Normal University President Dong Qi took office promised: don't declare new research subject in office, not recruit new graduate students, not to declare any teaching and research awards, individuals do not declare academician, to one hundred percent of the energy for the school management." Star fire could from the Yimeng area of Liaoyuan on local colleges and universities in the task of transformation and development in advance the reform of the governance structure of responsibility: college leaders should emancipate the mind, the courage to break the idea and 
system of imprisonment, to have top-level design strategist, boldness and courage, the courage to Open up a new situation; to understand that the university is not required for most official place, all university cadres are for teachers, students, teaching and research services; we must dare to break the idea of "official standard"," return to the academic standard, let the experts, Professor of in-depth teaching and research line. Yale University president Levin the university president must have eight the quality is local university leaders to learn, study and reference, these eight qualities are: at first ,it is to establish leading university forward vision, and can accurately convey; second, it is to develop and to achieve ambitious goals, in a progressive way forward, but once it has the opportunity to immediately seize and promote rapid change; third, the president is going to put a lot of time in active action, especially some strategic issues; fourth, taking risks, fifth, do not give up when face failures, good ideas worth several attempts; sixth, Knowing what time to take a top-down or bottom-up way to effect change is the most appropriate choice; seventh, it is a strong leader for the deputies have, give them enough freedom; eighth, it is to develop incentive mechanism to ensure the successful development and implementation of the combination of school personal goals.

\section{Innovation Leading Strategy}

Xi Jinping pointed out: "innovation is the soul of a nation's progress, it is an inexhaustible source of national prosperity, but also the Chinese nation's most distinctive national endowment." put forward in the fifth Plenary Session of the 18th CPC Central Committee: "insist on innovation and development, must take the core position in the global innovation of national development, and constantly promote theoretical innovation, institutional innovation, technological innovation the culture, innovation, make innovation through all the work of the party and country, make innovation become common practice in the whole society. The reform of the governance structure of local colleges and universities to implement innovative leading strategy means that the reform of the governance structure of local colleges and universities should enhance their awareness of innovation, to emancipate the mind, seek truth from facts for the principle, to respect the laws of Education under the premise of a variety of bold breakthrough system obstacle to the development of universities, in accordance with the" compliance with the party's education policy, whether the law of education and human development is in accordance with the law, Fair and impartial requirements "three standards to measure all teaching ideas and management system, and strive to achieve the transformation and development of higher education, the connotation of development and characteristics of development.

Innovation of Teaching Management System. Teaching quality is the lifeline of universities, improving the quality of personnel training in Colleges and universities is the core task of development and improve the quality of personnel training is the main battlefield of each link in the teaching activities. At present, the local teachers' classroom teaching in Colleges and universities teaching responsibility decline, impetuous, superficial, the pursuit of fame and fortune, became a utilitarian philosophy of life, teaching content boring, teaching the traditional method of teaching evaluation is single, one-sided irrational to become a common phenomenon. College students' learning enthusiasm is not high, passive learning, lazy, free class late, and leave early, playing mobile phone. Difficulties such as professional teachers meet the eye everywhere what effectively crack in the process of teaching, students learning difficulties and their plight; the top designers boldly implement innovative teaching management system. The core meaning of the teaching management system innovation: first, students management should be strict, eliminate the" strict easy out "Our college graduation rate of $95 \%$ for four consecutive years, while foreign students for six consecutive years, the graduation rate in only $40-60 \%$. In order to improve the quality of teaching in Colleges and universities, local colleges and universities students' academic guidance and amendment to the management opinions need bold breakthrough, according to the complete credit system thought of implementing academic management, strict regulations" after the appraisal did not reach the standard of training qualified students to retake courses or delayed graduation; the school shall not arrange any form before graduation clean-up examination; establish a sound academic warning and withdrawal system, to achieve professional graduation requirements of 
students, to repeat, according to the provisions for the transfer, drop out "[]. Second teachers, teaching management to have the scientific and humanistic resources are the first resources of College Teachers: teachers, teaching management should embody the people-oriented principle, establish management is service idea, in order to strengthen the realization of" Change monitoring oriented to incentive oriented management idea; at the same time, to follow the law of education and teaching, provide free teaching environment for teachers and students, plenty of library resources, humane development evaluation and incentive mechanism; to formulate policies to encourage teachers to adopt bold project oriented, task driven, situational experience, case simulation teaching, teaching reform teaching, encourage students to actively explore the change of learning styles, bold research learning and innovative learning.

Innovation of Personnel Management System. The innovation of local university governance structure reform in urgent need of personnel management system, according to a number of opinions about the current spirit to deepen the reform of personnel distribution system in Colleges and universities of the Ministry of education, in accordance with the bold introduction of competition mechanism, optimize the structure, change mechanism, according to the position, the principle of downsizing personnel system reform. Through the reform, the conversion mechanism, function adjustment, integration institutions, staff posts, and enhance the vitality; strengthen management, enhance the quality, form can, up and down, low energy competition atmosphere; strengthen employment, increase reorientation diversion under the premise of the establishment of on-demand Shegang, open recruitment, competition, survival of the fittest, contract management, strict examination of the appointment system the mechanism and position.

The main content of the reform of personnel system in Colleges and Universities: full optimization: in accordance with the set up principle, allocation, posts, responsibilities, all the staff on their own, can apply for the appropriate positions, diligence, performance, fair competition, preferred employ. Teacher: teacher class competition class from simple distribution type to one choose the type of class, the teacher listed class, students from the evaluation and selection of teachers; high level teachers preferred to select the curriculum implementation class, excellent reward principle, low level of teachers' classroom lessons or not any less, lower class allowance, long time no school teachers to be split. Evaluation of professional titles and the appointment of professional and technical positions: on the principle of separation can be hired, low vocational hire, low high school recruits; embodying the principle of competition in the evaluation of professional titles, breaking the practice level and pay attention to the actual promotion according to status, performance, to encourage young teachers to break talent shows itself. Gjigsson; promote the quantitative evaluation, objective evaluation index management. With hard hiring of Cadres: management cadre selection and promotion according to status to break the lifelong system, truly capable, concerning, the implementation of dynamic management; conditions of colleges and universities, the Party leadership in the school can understand education, through the audition selection procedures to understand management, experts have the ability. Scholars as the principal, school administration implemented by the principal to pick the "cabinet" approved by the organization; the middle management cadre of the implementation of the recruitment system and tenure system, all due to dismissal, re appointment, completely solve the problem can not only for life. The logistics service: logistic service socialized logistics service department to service. The quality of revenue, income over expenditure, self-financing, and in a similar market competition, the law of survival of the fittest, obvious income difference, the service is not good to be laid off.

\section{Acknowledgements}

Fund Project: in 2015 the Hunan province high school teaching reform research projects of transformation and development of local colleges and universities "theory and practice -- a case study of XiangNan University (Hunan taught through [2015]291); the education of Hunan province "in 12th Five-Year" planning project comprehensive reform Education under the background of Local Colleges and universities multi governance model research(XJK014BGD076), Development strategy research in applied technology university (XJK015BJD011). 


\section{References}

[1] K.P. Yu: Governance and Good Governance. (Beijing: Social Sciences Academic Press, 2000, $\mathrm{p} 4-5)$.

[2] Y. Chen: The characteristics and enlightenment of internal management system in Canadian university. Jiangsu Higher Education, (2007) No.5, p139.

[3] B.G. Peters: The Governance Model of Government in Future. (Beijing: China Renmin University Press. 2001, p25).

[4] B. Jessop: The rise and the risk of failure on governance: discussion based on economic development. International Society Science, (1999) No1, p45.

[5] J.KOOIMAN: Governance and govern ability: using complexity, dynamics and diversity. London: Sage, 1993, 4.

[6] V. Ostrom: The Political Theory of Composite a Republic. (Shanghai Joint Publishing Press, 1999, p210-211).

[7] J. Wang: An Vverview of the Contemporary Western Economics. (Beijing: National school of administration press, 1998, p123).

[8] Q.B. John,N. Merlin and H. Jiang translated: Political Market and School. (Beijing: Education Science Press. 2003, p140-142).

[9] S.J. Wang: Education record 2012: being an official or making money makes university entangled. China Youth News. 2012-12-25.

[10]J.L. Cai, Z.Y. Zhu and Z.W. Chen: Zhejiang enforces the higher education. China Education Press, 2015-5-21(05). 